Article

\title{
Spatiotemporal Agglomeration of Real-Estate Industry in Guangzhou, China
}

\author{
Peng Wang ${ }^{1}$, Xiaoyan Lin $^{1}$ and Dajun Dai ${ }^{2, *}$ \\ 1 College of Economics, Jinan University, 601 Huangpu Avenue West, Guangzhou 510632, China; \\ jnuwp@163.com (P.W.); miffy8807@163.com (X.L.) \\ 2 Department of Geosciences, Georgia State University, 24 Peachtree Center Avenue SE, Atlanta, \\ GA 30303, USA \\ * Correspondence: ddai@gsu.edu; Tel.: +1-404-413-5797; Fax: +1-404-413-5768
}

Received: 4 June 2017; Accepted: 11 August 2017; Published: 16 August 2017

\begin{abstract}
Real estate development is critical to healthy economic growth and regional development. Using real-estate data in Guangzhou, China from the 1970s to 2015, we examined the spatiotemporal agglomeration and evolution of Guangzhou's real estate industry with spatial and spatiotemporal techniques. This study shows that real estate businesses were initially agglomerated in the city center with socioeconomic advantages, and later spread into suburbs as new growth foundations. We also found that different business types, depending on their functions, evolved and agglomerated in different time periods. The findings provide valuable support to the formulation of effective government policy and the management of real estate enterprises in China.
\end{abstract}

Keywords: enterprise cluster; spatial evolution; spatiotemporal agglomeration; real estate industry

\section{Introduction}

Real estate plays an important role in economic growth worldwide, greatly influencing regional development, urbanization, and quality of life [1]. Real estate refers to the industry that engages land and buildings as business objects through various economic activities. These activities include land acquisition, project planning and design, construction and implementation, sales and later property management, aiming to create sustainable business profits by commercial facilities planning as well as long-term profits by managing and maintaining properties [2,3]. A sustainable development of real-estate enterprises will provide a healthy promotion and spillover effect to the local and regional economies. Meanwhile, the growth of other business types may also benefit from their association and investment related to real estate industry. In recent decades, real estate industry has become a critical driving force and predictive power of economic development. The economic meltdown in 2008 was largely attributable to the housing market crash and associated mortgage crisis. Therefore, it is of great value to examine the spatial distribution and evolution of real-estate industries to understand the economic development of urban and regional development.

In the field of real estate, little attention has been paid to the spatial distribution and evolution of real estate industry [4], although economists mainly analyze the relations between real estate economy and national economic growth, performance of real estate companies, correlation between real estate industry and capital market, real estate prices and real estate policies [5-7]. Examining industrial agglomeration and spatial evolution may shed light on the evolution rules of enterprise clusters [8], for example, how enterprises of the same kind accumulate in a particular space [9]. Findings from such studies have great potential to improve competitiveness power, create jobs and improve the living standards of local people [10-12], thus increasing returns to scale in urban and regional economy [13].

The spatial distribution and evolution of real estate industry is important to sustainable urban and regional development. It not only has direct influence on city design and layout through project 
planning, but also is closely related to urbanization process and urban land distribution [14,15]. As a basic industry of the national economy, real estate industry is the carrier of social reproduction and various economic activities, and an indispensable guaranty for the sustainable, healthy and stable development of regional and national economy. It provides physical space for residence and the supporting services for economic growth. The planning, development and construction of land, houses, and other public facilities become important parts of a city's infrastructure. In general, the economic efficiency of a modern city is determined by the rationalization of its demands and supplies, which are linked with the development of the real estate industry, transportation, etc. The spatial structure of the real estate industry can reflect the development of the city and provide predictive information for the future development direction of urban economy and planning. Therefore, examining the spatiotemporal agglomeration and evolution is necessary to understand the urban structure and create better dwelling environment for urban residents.

The development of real-estate industries in China requires special attention. China's real estate industry has experienced a tortuous development history. The independent real estate industry did not exist until China's reform and opening-up in 1978. After the reform of land and housing system, China's modern real estate industry gradually recovered and entered a period of stable and rapid development, becoming one of the pillar industries of China's national economy [16]. China's long-term planned economy in the past and the special nature of the real estate industry has determined that China's real estate industry is inseparable from the governments. Government development plans have great influence on the economic growth and spatial agglomeration of the real estate industry [17]. In recent decades, housing has become a new consumption hotspot in China, which leads to sky-rocketing and unaffordable housing prices. To control housing prices, local governments introduce a number of regulation and control policies for the real estate industry [18]. Housing price is influenced by various factors and varies spatially $[19,20]$. Studying the spatial distribution of real estate industry can provide in-depth understanding on the relation between industry development and housing demand. This may be useful to urban planners and policy makers to regulate housing markets for a more balanced city development. Therefore, it is vital to critically evaluate the spatial clustering and evolution of Chinese real-estate development.

In this paper, we raise an important research question: how does real estate industry evolve and agglomerate in space and time? Specifically, using geospatial techniques in Geographic Information Systems (GIS) and Guangzhou as a case study, we: (1) identify the spatial distribution of three types of real-estate businesses since Chinese economic reform in 1978; and (2) assess the space-time clustering and agglomeration in the three real-estate types. Findings of this research are valuable to provide information for the rational use of urban land, the effective formulation of government policy and the management of real estate enterprises.

\section{Theoretical Review}

The spatiotemporal agglomeration of enterprises refers to a sequential process which mainly includes the initial stage and the subsequent post-stage of self-growth and development in space and time [21]. Inter-enterprise cooperation, co-procurement of raw materials, reduction of transaction costs, exchange of technology and sharing of financing and logistics channels are the primary power source for the post-stage of enterprise clustering in space [22-24]. The spatial expansion of industry in the post stage is considered an automatic process without government intervention. However, some studies argued that clustering advantage only plays a limited role in enterprise clustering $[25,26]$ and the formation of enterprise clusters in different regions have different development and dynamic change regularity [27].

Knowledge of this spatiotemporal clustering will be useful to economic stimulation for healthy development and regional economic upgrading. This economic clustering may not only minimize "transport and transaction costs between locally based suppliers, subcontractors and assemblers, and lower costs of accessing specialized labour", but also maximize "enterprises of access to localized 
and relatively immobile tacit knowledge", and "knowledge spillovers" [28] (pp. 72-73). With the continuous development of modern manufacturing, the supporting knowledge-intensive business services (KIBS) group around its surrounding areas and form integrated clusters. Universities and other researching institutions play an important role in fostering knowledge intensive clusters $[29,30]$. From the perspective of talents and technology sharing, KIBS industries tend to agglomerate around universities, research institutes, and scientific parks [31,32]. However, they are different from real-estate industries because of the differences in their products and service focus. For example, residential property management businesses in real-estate industries will be influenced by the need for and benefits of proximity and accessibility to both its demands (residents) and supplies (utilities). As enterprise cluster studies play an important role in regional studies, inter-regional cluster studies and policy-making of specific regions [9], studying the agglomeration of this particular industry may offer unique contribution to this area of research.

Spatial agglomeration of related industries can be distinguished into three models: the model of pure agglomeration, the industrial-complex model and social network model [33]. The model of pure agglomeration emphasizes that industrial agglomeration can be attributed to three reasons, which are enterprises' pursuit of external economies of scale through labor market pooling, intermediate goods investment and technology spillovers [28,34]. The industrial-complex model believes that the clustering behavior of enterprises is greatly influenced by the trading links between enterprises as well as the transaction costs [35]. Social network model focus on the trust relation between enterprises and believe that strong interpersonal relationships can increase the social relation between enterprises [33].

Spatial econometric models are usually used to examine the spatial distribution of real estate industry [36,37], yet it is still necessary to investigate its spatial evolution and agglomeration. Spatial location and the development of surrounding industries have a direct impact on the structural equilibrium of real estate market. Since the location of real estate has a direct impact on its value and its appreciation potential [38], some scholars described the location characteristics of real estate projects from the perspective of geography, and explored issues such as housing spatial structure, residential location and living space selection [39-43]. Although previous studies have used various spatial techniques, such as spatial autocorrelation analysis [44,45] or spatial interpolation [46], the spatial clustering behavior and spatial evolution requires consideration of the interaction between space and time. The aforementioned techniques, however, are less applicable to data on spatiotemporal dimensions. In this research, we propose using space-time clustering techniques to understand the spatiotemporal clustering and evolutionary nature of real-estate businesses.

\section{Research Design}

\subsection{Study Area and Data Sources}

The study area is in Guangzhou (Figure 1), a centuries-old trading port and political, economic, cultural, and scientific center in Southern China. Located on the Pearl River, Guangzhou is the capital of Guangdong Province about $120 \mathrm{~km}$ north-northwest of Hong Kong and $145 \mathrm{~km}$ north of Macau. The Guangdong-Hong Kong-Macau Greater Bay Area Initiative is a recent national strategy to highlight the region's role and competition in the global economy including manufacturing, transportation, trade, and innovation industry. The city has one of the most developed and mature real estate industries in China, which makes the study area appropriate for this research. The study area (7434.4 square kilometers with 14 million population) includes 12 administrative districts (Figure 1) in three development zones, depending on each district's development sequence and location. The central urban area includes Tianhe District, Yuexiu District, Liwan District, Haizhu District, and Baiyun District. The suburban area mainly refers to the closer proximity of the central urban area, including Panyu District, Luogang District, Huangpu District and Huadu District. The outer zone includes Zengcheng District, Conghua District and Nansha District. As can be seen in Figure 1, Tianhe District serves as the 
Guangzhou Central Business District (CBD), where many corporation headquarters, office buildings, and financial companies are located.

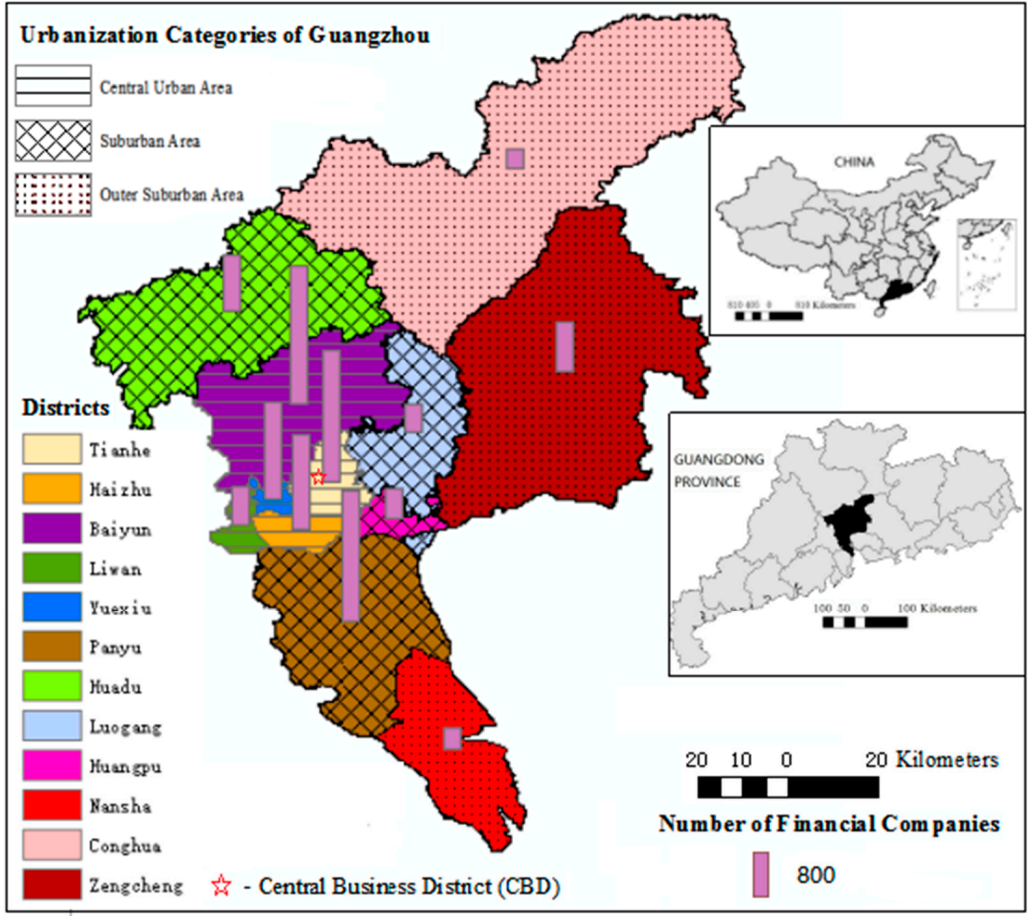

Figure 1. Study area, City of Guangzhou, Guangdong Province, China.

We collected real estate business data $(n=1269)$ from Guangzhou Commercial Information Display Platform [47] and Guangdong Statistical Yearbook [48]. We categorized the businesses into three groups: real estate development companies, real estate agents, and property management companies. Real estate development companies are engaged in real estate development for profits, involving urban land development, housing construction, infrastructure construction, real estate marketing, etc. Real estate agents mainly include real estate advisers, real estate appraisal agencies and real estate brokers, and so on. Property management companies refer to the companies which provide property management services to residential communities and commercial buildings, including maintenance of after-sale or leased properties, cleaning and greening of residential areas, security, housing leasing, house decoration, moving services, and other business services. We then geocoded the companies using their addresses (only headquarters are available), and obtained their latitudes and longitudes for mapping and spatial analysis purpose. Eighty-eight companies (6\%) have either incorrect addresses or missing establishment dates, and were excluded from the analysis. In total, there are 1181 valid items of real estate businesses in the analysis.

\subsection{Methodologies}

The initial analysis focused on the distribution of all real-estate businesses in time and space. The temporal analysis examined the overall growth of all three business types over the last 30 years. We then examine their geographic distribution using median center and kernel density estimation by the three business types. Median center measures the central tendency that is robust to outliers $[49,50]$. It identifies the location that minimizes the distance from it to all businesses. By plotting the median center of each real-estate type over time, it will shed light on the spatiotemporal trajectory of real estate growth.

The Kernel density estimation (KDE) is a data smoothing technique used to evaluate where the real-estate businesses are concentrated. It estimates the density at each location as the average 
value within a search radius, or the bandwidth $h$, around it by weighting objects nearby more than ones far away based on a kernel function [51]. This study uses the built-in KDE tool in ArcGIS based on the widely used quartic function. The cell size is set as 0.0005 and the bandwidth is 0.02 . The output area unit is square kilometers. Previous studies have proposed several methods to determine the best kernel function or the optimized $h$, yet Epanechnikov [52] found that the choice among various kernel functions does not significantly affect the outcome of the process. To incorporate the temporal dimension into the analysis, we separate the data into a series of time intervals and run KDE separately. By doing so, the analysis transforms a layer of discrete features, i.e., real-estate businesses, to a continuous raster surface, thus identifying the distribution trend over the time. The KDE value at a location can be interpreted as the relative concentration of real-estate businesses around a place.

The subsequent analysis is to examine the clustering real-estate businesses using global and local spatial statistics. The global measure employs average nearest neighbor analysis, followed by a local measure using the space-time scan statistic in SatScan (www.satscan.org). Although the KDE model provides a lens of spatial concentration of the businesses over time, the significance of such concentration remains unanswered.

Nearest neighbor analysis measures the distance between each event (i.e., real-estate business) and its closest neighbor's location. It then averages all these distances. If the average distance $(O)$ is less than the average $(E)$ for a hypothetical random distribution, that is the nearest neighbor ratio of $O / E$ is less than 1, the distribution of the events is considered clustered. In ArcGIS, the nearest neighbor analysis tool uses z-scores to determine the significance $[53,54]$. In this analysis, we test the global clustering of each business type in a five-year interval.

Locating clusters of the three real-estate business types allows one to examine the factors that could explain the development of the real-estate economy. As a popular software, SatScan has reasonable sensitivity and specificity compared to other clustering methods [55]. Besides, compared to the spatial analysis approaches above based on the subjectively selected time intervals, SatScan does not restrict the search space and time, thus providing a more flexible solution to detect clusters. However, no studies have used it to investigate real-estate evolution, which is a novel contribution of our research.

This study uses the Bernoulli model in SatScan to identify the space-time clusters of each real-estate business type. The Bernoulli model is essentially to test the distribution of cases against controls. The null hypothesis assumes the two distributions are the same. In other words, the number of cases at a location in a period is proportional to the number of controls. The alternative hypothesis is that some geographical areas have more cases than what is expected based on the control numbers. SatScan imposes a conic search window moving in both space and time to test the difference between the two distributions in a search window. To evaluate the significance of the difference, SatScan then employs a likelihood ratio tests and the Monte Carlo simulation using 999 randomizations. To construct the Bernoulli model, we use one real-estate business type as cases (e.g., real-estate development businesses) and the other two types as controls (e.g., real-estate agents and management businesses). The time interval is designated as one year because the real-estate businesses are less likely to change frequently at monthly or weekly intervals. We then repeat this process by alternating the other two types of businesses as cases, respectively. The results will allow us to identify the significant clustering of each type of real-estate businesses in the study area in certain years.

\section{Results}

\subsection{Spatial Distribution and the Space-Time Central Tendency of Guangzhou's Real Estate Industries}

Based on the number of real estate enterprises in Guangzhou, Guangzhou real estate development can be divided into three stages, 1985-1995, 1996-2010 and 2011-2015 (see Figure 2). From 1985 to 1995, Guangzhou real estate industry was in the initial stage of development. Although the number of 
real estate enterprises was quite small, the growth rate was high with an average annual growth rate of $32.19 \%$. From 1996 and 2010, the development of Guangzhou real estate industry slowed down with an average annual growth rate of $11.43 \%$. However, after 2011, the number of real estate enterprises grows at a faster rate again.

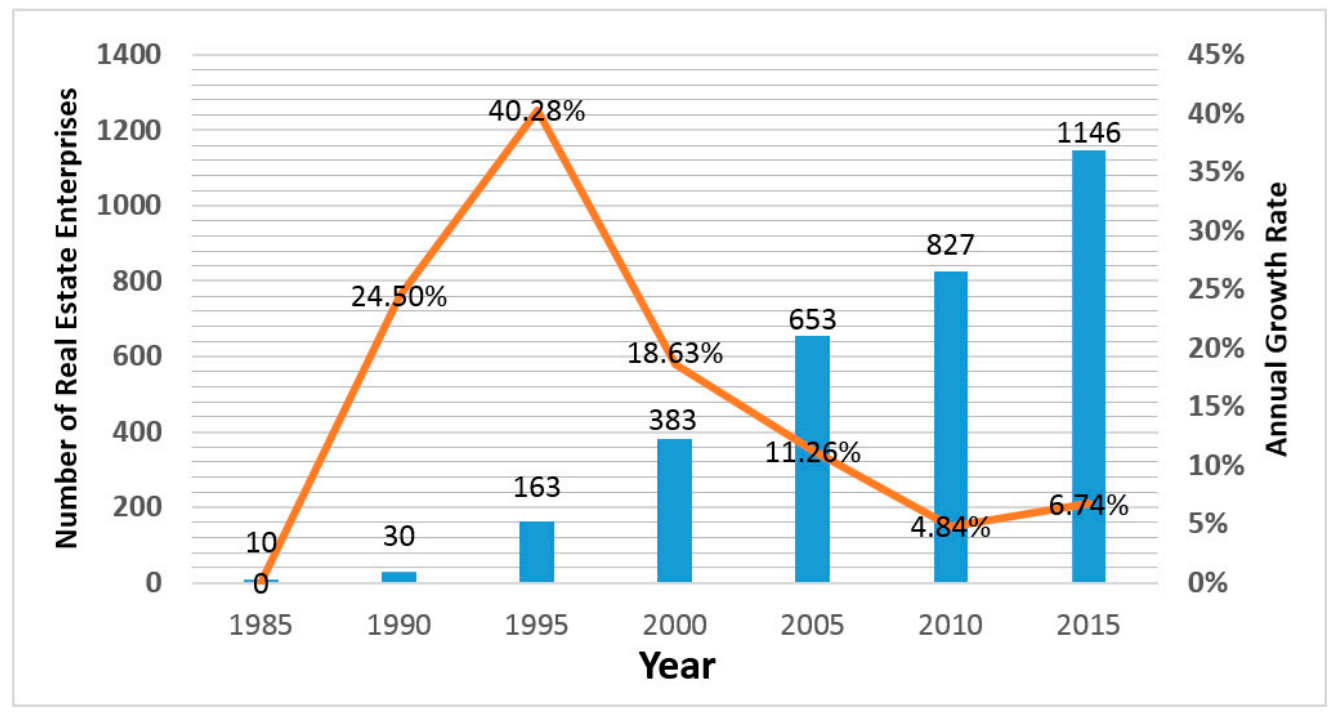

Figure 2. Growth of real estate industry in Guangzhou (1985-2015). The orange line and blue bars represent the annual growth rate and number of real estate enterprises, respectively.

Mapping median centers (Figure 3) suggests the cluster center of Guangzhou real estate enterprises was located in Tianhe District in the early period of enterprise cluster, and then moved around the boundary of Yuexiu District and Tianhe District. In fact, industrial development and clustering are positively correlated with urbanization, economic development, regional development, housing consumption demand and government investment expenditure. After the 1990s, with strong government political and financial support, social economy and urbanization degree of Tianhe District and Yuexiu District continue to increase and gradually become the most economically developed regions in Guangzhou. During 2005 and 2015, the top three areas with the highest contribution to Guangzhou's GDP are Tianhe District, Yuexiu District and Luogang District, which are more than 10\%, while the contribution rate of outer suburban area such as Conghua District, Zengcheng District and Nansha District is relatively small.

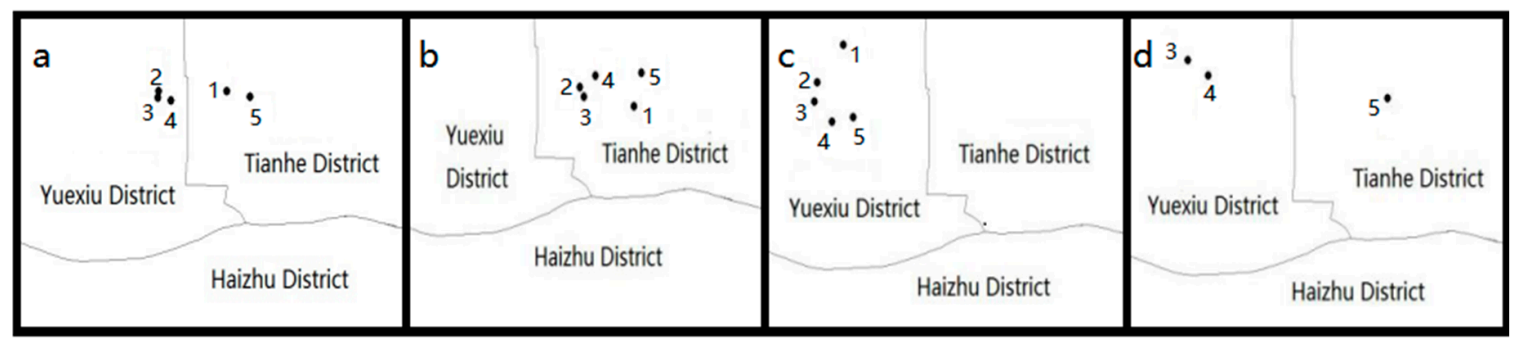

Figure 3. Trajectory of median center of Guangzhou real estate industry. (a) Real Estate Industry in total; (b) Real Estate Development Company; (c) Property Management Company; (d) Real Estate Agent. Notes: numbers represent the following time intervals: 1, 1985-1995; 2, 1995-2000; 3, 2000-2005; 4, 2005-2010; and 5, 2010-2015. 
Real estate development companies are mainly clustering in Tianhe District (Figure 3b). As a capital intensive company, real estate development companies require a lot of funds and talents to support its projects in the process of operation and management, so it is necessary for real estate development companies to establish a close relation with banks and other financial institutions. After years of development, Tianhe District has become the financial center of Guangzhou. Locating in Tianhe District is conducive for real estate development companies to solve the funding problems. Comparatively speaking, the number of commercial buildings and financial companies in outer suburban area is far less than that in Tianhe District and Conghua District. Outer suburban area is the region that develops most slowly in Guangzhou.

The cluster center of property management companies (Figure 3c) is in Yuexiu District. Yuexiu District is not only rich in historical and cultural resources but also the administrative, commercial, financial and cultural center of Guangzhou. Its unique geographical advantage has supported an industrial pattern with mainly tertiary industries. Office buildings are crowded in Yuexiu district, which bring a highly intensive rate of labor flow, capital flow and information flow. Total retail sales of consumer goods, merchandise sales and other economic indicators of Yuexiu District are ranked top among Guangzhou's 12 districts. However, the residential buildings (mainly apartments), for both permanent registered residents and temporary workers, greatly outnumbered the office buildings. As "community business" and "convenience services" are very important for property management companies, and in order to provide services to the residents as fast as possible, property management companies are inclined to gather around residential properties. Interpreting this pattern, however, shall take caution because the size of the property management companies is not considered in this research. Therefore it is possible that some large property management companies are located closely to office buildings too [56].

Since the concentration of real estate agents is relatively late, this paper only selects three median center points to study the central movement rules of real estate agents (see Figure 3d). From 2000 to 2015, the median center of real estate agents is moving from west (Yuexiu) to the east (Tianhe). At present, real estate agents are mainly small scale private enterprises. Influenced by economic development and urbanization, real estate agents are mainly grouped in the areas with high population mobility, high effective housing demand and high housing prices. Tianhe District and Yuexiu District are the most developed commercial areas in Guangzhou, which have attracted a large number of migrant population. Strong rental demand, rapid population flow and high income in these two districts create precious development opportunities for real estate agents.

The KDE analysis on all businesses together and separately (Figures 4 and 5) suggested that the real estate enterprises followed the city's urbanization trend. They moved to where the city is growing from the urban center to near suburbs, and then to outer suburbs. The property management firms are clustered around existing housing properties. In general, the level of Guangzhou real estate enterprises was low and mostly in the city center in the early 1990s. In 2005, an initial growth kernel appeared in suburban areas such as Huadu District and Panyu District while the distribution density of the real estate enterprises in the outer suburban area, far away from central urban suburbs, was still very low. In recent years, with increasing scale and density of real estate enterprises in Guangzhou central urban area, the real estate enterprise cluster begin to spread to the suburban area, resulting in largely increasing enterprise distribution density in the suburbs. In addition, some high-density kernels begin to appear in outer suburban area. The closer to the central urban area, the higher kernel strength and scale is. The real estate industry has a significant tendency to migrate and proliferate to the surrounding area of central urban area. 


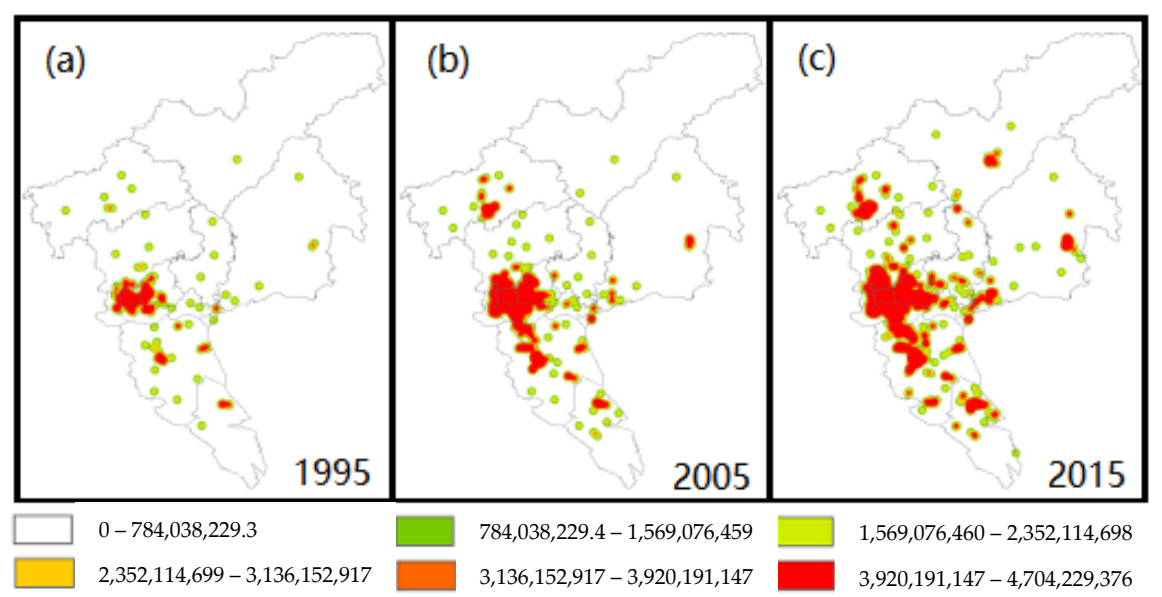

Figure 4. Kernel density analysis on Guangzhou real estate enterprises (1995, 2005, and 2015). (a) Kernel density analysis on Guangzhou real estate enterprises in 1995; (b) Kernel density analysis on Guangzhou real estate enterprises in 2005; (c) Kernel density analysis on Guangzhou real estate enterprises in 2015.

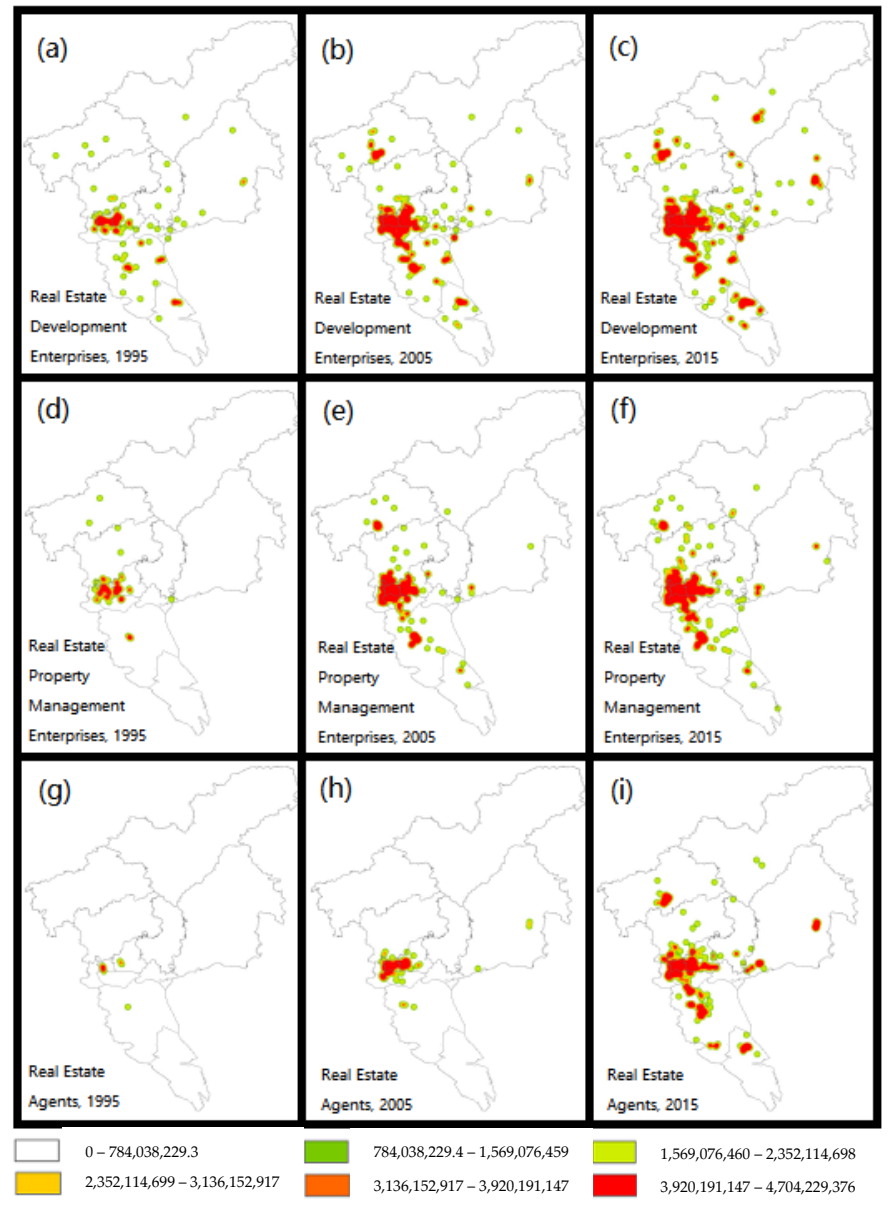

Figure 5. Kernel density analysis on Guangzhou real estate development enterprises (a-c), real estate property management enterprises (d-f) and real estate agents (g-i) in 1995, 2005, and 2015, respectively. 


\subsection{Space-Time Clustering of Real-Estate Businesses in Guangzhou}

The Nearest Neighbor Analysis reveals the spatial distribution of Guangzhou real estate industry (see Table 1). The clustering pattern suggests industrial spatial evolution in Guangzhou's real estate industry with different historical characteristics of dispersion, randomness and clustering. According to ANN index, the real estate industry in Guangzhou was randomly distributed from 1985 to 1990, as the economy of Guangzhou was not yet developed and the real estate industry had just started. There were only a few real estate enterprises in the market distributing widely in the city. Thus, it was difficult to form geographic concentrated areas in that period. After 1995, with the development of Guangzhou's economy, real estate industry developed rapidly and began to show a clustering-type distribution. The degree of enterprise clustering increases continuously.

Table 1. Average nearest neighbor index of Guangzhou real estate industry, Guangzhou real estate development company, real estate agent and property management company.

\begin{tabular}{cccccccc}
\hline Year & $\mathbf{1 9 8 5}$ & $\mathbf{1 9 9 0}$ & $\mathbf{1 9 9 5}$ & $\mathbf{2 0 0 0}$ & $\mathbf{2 0 0 5}$ & $\mathbf{2 0 1 0}$ & $\mathbf{2 0 1 5}$ \\
\hline Real estate industry & $1.04^{\mathrm{R}}$ & $0.98^{\mathrm{R}}$ & $0.56^{\mathrm{C}}$ & $0.42^{\mathrm{C}}$ & $0.36^{\mathrm{C}}$ & $0.38^{\mathrm{C}}$ & $0.34^{\mathrm{C}}$ \\
Number of real estate companies & $11^{\mathrm{C}}$ & 31 & $164^{\mathrm{C}}$ & 384 & 654 & 828 & $1183^{\mathrm{C}}$ \\
Real estate development company & $1.98^{\mathrm{D}}$ & $1.12^{\mathrm{D}}$ & $0.64^{\mathrm{C}}$ & $0.50^{\mathrm{C}}$ & $0.42^{\mathrm{C}}$ & $0.42^{\mathrm{C}}$ & $0.39^{\mathrm{C}}$ \\
Property management company & $2.59^{\mathrm{D}}$ & $1.89^{\mathrm{D}}$ & $0.74^{\mathrm{C}}$ & $0.54^{\mathrm{C}}$ & $0.46^{\mathrm{C}}$ & $0.38^{\mathrm{C}}$ & $0.38^{\mathrm{C}}$ \\
Real estate agent & - & $286.3^{\mathrm{D}}$ & $1.44^{\mathrm{D}}$ & $1.04^{\mathrm{R}}$ & $0.53^{\mathrm{C}}$ & $0.42^{\mathrm{C}}$ & $0.36^{\mathrm{C}}$ \\
\hline
\end{tabular}

Notes: ${ }^{ }$, Random; ${ }^{\mathrm{D}}$, Dispersed; ${ }^{\mathrm{C}}$, Clustered.

There are some differences in the spatial evolution of these three types of real estate enterprises. In 1985, the real estate development companies were dispersed and then slowly concentrated. After 1995, the spatial distribution of real estate development companies presented an agglomerating situation. At the same time, the spatial distribution of property management companies show similar spatial evolution path with real estate development companies, dispersed before 1995 and then clustered, and the clustering degree increased year by year. Moreover, the spatial distribution of real estate agents was dispersed in 1995 and then random in 2000. With increasing demand for real estate intermediary services, the spatial distribution of real estate agents began to agglomerate after 2005 .

Table 2 is a summary of the spatial evolution characteristics of the real-estate businesses. It shows that, from 1985 to 2015, the spatial distribution of Guangzhou real estate industry, overall as well as the three types of real estate enterprises, evolved from random to clustered. However, the real estate agent is the latest one to form geographic clustering.

Table 2. Spatial evolution characteristics of Guangzhou real estate enterprises.

\begin{tabular}{ccc}
\hline Type & Agglomeration Degree & Cluster Spatial Evolution Direction \\
\hline Guangzhou Real Estate Industry & high & periphery-central urban area-periphery \\
Real Estate Development Company & high & periphery-central urban area-periphery \\
Property Management Company & quite high & central urban area \\
Real Estate Agent & low & central urban area \\
\hline
\end{tabular}

Figure 6 reveals the clusters of three types of real-estate businesses. In general, the agglomeration of development businesses was the earliest, followed by management businesses and then agents. Specifically, real-estate development businesses formulated two clusters, one was in the city center (1987-1997) and the other was largely in the southeast area (2000-2014) near Cencun airport. Real-estate management businesses were significantly clustered in the city center (1994-2014) and Panyu (1998-2009). Clusters of real-estate agents were located in the city center (2008-2015) and the southeast suburbs (2009-2015). 


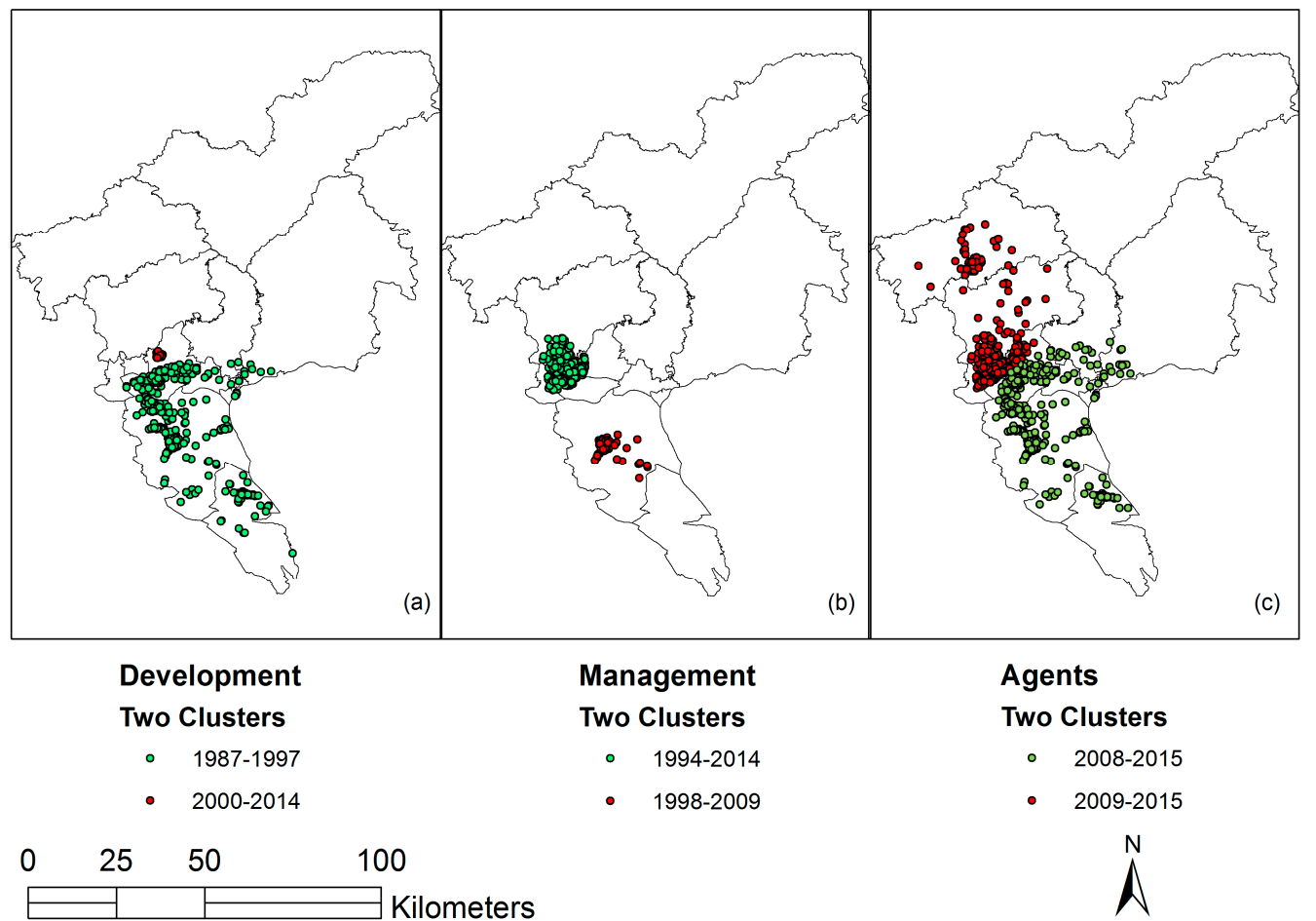

Figure 6. Space-time clustering of three business types: (a) development companies; (b) management companies; and (c) agents.

\section{Discussion}

Questions arise as to whether development of real-estate businesses has any spatiotemporal pattern that can be used to plan future economic policy. This study contributes to this line of research by examining the spatiotemporal trend of real-estate businesses in Guangzhou in the last 40 years using geospatial techniques. It is evident that the three types of businesses present distinct patterns in different periods.

Our research revealed that Guangzhou real estate industry was mainly concentrated in Yuexiu District and Tianhe District. According to the 2015 Guangzhou Statistical Yearbook [57], GDP of Yuexiu District and Tianhe District, respectively, accounted for $14.89 \%$ and $18.96 \%$ of Guangzhou GDP, with growth rates of $10.39 \%$ and $9.35 \%$. Serving as the central business district, the two districts are the most rapidly developed and prospective area in Guangzhou. This is consistent with previous research [58] that enterprise clusters tend to formulate in areas with high social and economic development because it is cost-effective to obtain resources at low cost and get industry-related information and technology spillover. In these two districts, economic base and supporting services provide favorable opportunities to the agglomeration of real estate enterprises. As industrial development is closely linked with regional urbanization, local government may take advantage of the urbanization opportunities and promote the development of enterprises cluster. At the same time, guided by enterprise clusters, policy makers may develop plans for labor flow between regions, stimulate enterprise technological innovation, improve urban infrastructure and urban environment, and create more jobs and optimize enterprise spatial layout. Such enterprise clustering will help speed up the regional economic restructuring. By allocating resources required in new urban spaces, the planning agencies may invest key areas that are of economic importance such as strategic reserves of natural resources, telecommunication infrastructure, power grids, etc. This will reduce uncertainty for the economy and thus promote the overall sustainable development of the region. 
Our findings also suggest that each of the three different types of real estate businesses developed agglomeration in certain periods. The development businesses formulated the earliest agglomeration followed by the real-estate property management businesses and agents. Prior to the economic reform in 1978, China did not have market-based real-estate industries [59]. Since the central government chose Guangzhou as a test site for real-estate market development in 1981, real-estate development businesses arose quickly and agglomerated early in the city [60]. Real-estate management businesses are centered on services, which did not quickly develop until the demands from communities were formulated. The need for agents was mainly from the new real estate markets, rental businesses, and second-hand property transactions. Therefore, agent clustering was the latest to agglomerate. In recent years, as less space become available and increased cost in the central urban area (or the core area), these businesses started to move to southeast suburbs. For example, Panyu and Luogang Districts provide convenient rapid transits, infrastructure, and low operation costs [61]. Therefore, the southeast suburbs present great potentials for real-estate businesses, which explains their agglomerations there. Businesses of the same type tend to distribute closely with each other because of the convenient access to supplier services and ancillary products and services, thereby enhancing survival rate and market competitiveness. The lagged agglomeration of real-estate agents is attributed to the transition of planning economy to a market-based economy, thus providing opportunities of commercialization of properties and facilitating the growth of real-estate agents.

Overall, the real-estate businesses in our research agglomerated in the economically developed districts in the central urban areas, and then spread to near and outer suburbs. At each location, when the agglomeration level reaches a certain degree, enterprises in cluster will spread to the surrounding areas, which will promote the industrial development in suburban areas. The government agencies may take advantage of enterprises' spatial distribution behavior to successfully achieve industrial transfer. In the early stage of industrial development, economically developed regions are more competitive than other regions. Enterprises with similar products and related professional external service industries and supporting facilities will be transferred from underdeveloped regions to the developed region, thus bringing external economies of scale, creating social value and increasing employment opportunities $[62,63]$. Similar enterprises and affiliated enterprises are quickly grouped in a small part of a region to form a preliminary enterprise cluster and successfully absorb local knowledge without high investment in R\&D [64]. However, with increasing degree of enterprise agglomeration and market saturation, it is difficult for regional economy, market and land space to support enterprises cluster with too high density and the enterprises within the cluster especially the new entrants are unable to obtain new development opportunity and capacity breakthrough among such a large number of enterprises. It is necessary to guide some enterprises transfer to the surrounding areas and form a new growth pole of enterprises cluster, so that enterprises cluster are no longer confined to a certain small area in the region but grow into several mutually connected growth poles, thereby enhancing the utilization of regional resources and promote the overall development of the regional industrial economy.

The clustering behavior of industrial clustering above reveals the economic mechanism behind. The agglomeration is associated with reduced transportation expenses and resource costs due to relocation to concentration, which is in line with the literature [35]. Our findings revealed that the clustering area of real estate industry in Guangzhou transferred from the high-cost urban center to suburbs for lower cost and higher economic returns through internal and external economies of scale, reduction in transaction costs, increasing competition, and innovation promotion [28,33]. Reasoning behind this industrial clustering is complex. On the one hand, the agglomeration results from profit maximization and thus increases the economic efficiency and competitiveness of the industry. Policies may benefit from foreign investment and economic reconstruction responding to the agglomeration dynamics $[65,66]$. On the other hand, policies might have played an influential role during the agglomeration process. Governmental agencies play an important role in economic development and urban planning, such as infrastructure development, providing incentives and positive 
environment for economic growth of the industries and cost reduction [67]. Although systematic urban planning provides a pre-determined layout of a city, but the actual space development may be influenced by various factors other than economic clustering [68].

Associated with the clustering of the real-estate industries are soaring housing prices in China, which has important implications. Despite massive privatization and shift to free markets, Chinese government still retains ultimate land ownership but sells land-use rights and determines its housing market development. The central government deemed the free market as the avenue for housing allocation in 1998. Since then, Chinese housing prices grew explosively and became the major investment focus [69]. Our research echoed this trend by revealing that all three real-estate businesses had been spatially clustered in the last two decades. Although the central government recently made intervention policies including higher mortgage down payment, pilot property tax, prohibitions on purchasing multiple houses by the same household, and the suspension of non-local purchasing [70], local governments have strong incentive and capability to generate significant revenue from the sale of land-use rights [69]. Thus, developing land (especially agricultural use) into dwellings in markets is still favored locally, and will continue under supportive local government's urban development plan. However, such soaring housing prices and explosive urban growth raise serious questions about the suitability of not only the economy, but also the environment. Because of China's growing economic importance with high global interests among investors, more studies of real-estate development in China are needed.

Our findings may be subject to some limitations. First, this paper uses the GIS spatial analysis tool to analyze enterprises spatial distribution and evolution behavior from the macroscopic level. However, this paper cannot further explore the influence of microcosmic factors such as firm size, productivity, and employment on the spatial evolution behavior of enterprises because these are not available to the public. Second, our research is limited by using the locations of the headquarters, not the locations of their projects or managed buildings because of data unavailability. Future research may need to explore the impact of corporate profits and size on the spatial distribution and use the actual locations of the projects or buildings if possible. Third, our study focuses on the distribution of each real estate type while controlling the other two, however, it does not consider the interaction among the three types. How would these businesses interact between different types or within the same type? How would such interactions influence the clustering of each business type? These questions warrant further analysis when such data become available. Fourth, government policies play an important role in the development of enterprise clusters in China. Future research may integrate government policy as an important influencing factor of enterprise cluster development using a more accurate enterprise agglomeration index, such as Entropy Index [71], Space Gini Coefficient [13], EG Index [72] and DO Index [73]. Such an integration may provide a better in-depth understanding of the spatiotemporal pattern of enterprises, for instance, agglomeration characteristics, influencing factors, and cluster network relations.

In summary, this study examined the spatial distribution and evolution of real-estate businesses using geospatial techniques in Guangzhou. The findings may assist in evaluating the geographic agglomeration of enterprises and provide evidence for economic policy makers to provide sustainable development of economy. Clusters of the specific types of enterprises provide important guidance to industrial development and transfer targeting these businesses.

Acknowledgments: This research was supported by grants from National Natural Science Foundation of China (71673112), and project of Key Research Base for Humanities and Social Sciences of Guangdong Province, China-Research Center for the Industrial Development of Guangdong and Its Regional Cooperation with Hong Kong, Macau and Taiwan (Jing Wei Center for Economic Research on Guangdong, Hong Kong and Macau) (37714001004).

Author Contributions: D.D., P.W., and X.L. conceived and designed the research. D.D. led the research method design and provided technical guidance. P.W. and X.L. collected and cleaned the data. All have contributed to the manuscript preparation.

Conflicts of Interest: The authors declare no conflict of interest. 


\section{References}

1. Zhang, H.; Li, L.; Chen, T.; Li, V. Where will China's real estate market go under the economy's new normal? Cities 2016, 55, 42-48. [CrossRef]

2. Kummerow, M.; Chan Lun, J. Information and communication technology in the real estate industry: Productivity, industry structure and market efficiency. Telecommun. Policy 2005, 29, 173-190. [CrossRef]

3. Lee, J.; Tang, W. The hegemony of the real estate industry: Redevelopment of 'Government/Institution or Community' (G/IC) land in Hong Kong. Urban Stud. 2016. [CrossRef]

4. Wilhelmsson, M. Spatial models in real estate economics. J. Hous. Theory Soc. 2010, 19, 34-45. [CrossRef]

5. Forrest, D. An analysis of house price differentials between English regions. Reg. Stud. 1991, 25, $231-238$. [CrossRef]

6. Hollya, S.; Pesaran, M.H.; Yamagata, T. The spatial and temporal diffusion of house prices in the UK. J. Urban Econ. 2011, 69, 2-23. [CrossRef]

7. Anundsen, A.K.; Gerdrup, K.; Hansen, F.; Kragh-Sørensen, K. Bubbles and crises: The role of house prices and credit. J. Appl. Econ. 2016, 31, 1291-1311. [CrossRef]

8. Moodysson, J.; Sack, L. Institutional stability and industry renewal: Diverging trajectories in the Cognac beverage cluster. Ind. Innov. 2016, 23, 448-464. [CrossRef]

9. Delgado, M.; Porter, M.E.; Stern, S. Defining clusters of related industries. J. Econ. Geogr. 2015, 16, 1-38. [CrossRef]

10. Pyke, F.; Sengenberger, W. Industrial Districts and Local Economic Regeneration; International Institute of Labor Studies: Geneva, Switzerland, 1992.

11. Giuliani, E. Cluster absorptive capacity. Eur. Urban Reg. Stud. 2005, 12, 269-288. [CrossRef]

12. Morrison, A.; Rabellotti, R.; Zirulia, L. When do global pipelines enhance the diffusion of knowledge in clusters? Econ. Geogr. 2013, 89, 77-96. [CrossRef]

13. Krugman, P. Geography and Trade; The MIT Press: Cambridge, MA, USA, 1991.

14. Haque, A.; Asami, Y. Optimizing urban land use allocation for planners and real estate developers. Comput. Environ. Urban Syst. 2014, 46, 57-69. [CrossRef]

15. Goldberg, A. Urban planning and real estate development. Urban Des. Int. 2011, 16, 145-146. [CrossRef]

16. Jiang, D.; Chen, J.J.; Isaac, D. The effect of foreign investment on the real estate industry in China. Urban Stud. 1998, 35, 2101-2110. [CrossRef]

17. Barbieri, E.; Di Tommaso, M.R.; Huang, M. Industrial development policy and innovation in Southern China: Government targets and firms' behaviour. Eur. Plan. Stud. 2010, 18, 83-105. [CrossRef]

18. Chow, G.C.; Niu, L. Housing prices in urban China as determined by demand and supply. Pac. Econ. Rev. 2015, 20, 1-16. [CrossRef]

19. Zheng, S.; Sun, W.; Wang, R. Land supply and capitalization of public goods in housing prices: Evidence from Beijing. J. Reg. Sci. 2014, 54, 550-568. [CrossRef]

20. Tillmann, P. Capital inflows and asset prices: Evidence from emerging Asia. J. Bank. Financ. 2013, 37, 717-729. [CrossRef]

21. Braunerhjelm, P.; Feldman, M. Cluster genesis: Technology-based industrial development. Econ. Geogr. 2008, 84, 245-246. [CrossRef]

22. Van Diermen, P. Local enterprises in the global economy: Issues of governance and upgrading-Edited by Hubert Schmitz. Growth Chang. 2006, 37, 320-322. [CrossRef]

23. Casper, S. How do technology clusters emerge and become sustainable? Social network formation and inter-firm mobility within the San Diego biotechnology cluster. Res. Policy 2007, 36, 438-455. [CrossRef]

24. Van Egeraat, C.; Curran, D. Spatial concentration in the Irish pharmaceutical industry: The role of spatial planning and agglomeration economies. Tijdschr. Econ. Soc. Geogr. 2013, 104, 338-358. [CrossRef]

25. McCann, P. Rethinking the economics of location and agglomeration. Urban Stud. 1995, 32, 563-577. [CrossRef]

26. Malmberg, A.; Malmberg, B.; Lundequist, P. Agglomeration and firm performance: Economies of scale, localisation, and urbanisation among Swedish export firms. Environ. Plan. A 2000, 32, 305-321. [CrossRef]

27. He, Z.; Rayman-Bacchus, L.; Wu, Y. Self-organization of industrial clustering in a transition economy: A proposed framework and case study evidence from China. Res. Policy 2011, 40, 1280-1294. [CrossRef]

28. Keeble, D.; Nachum, L. Why do business service firms cluster? Small consultancies, clustering and decentralization in London and southern England. Trans. Inst. Br. Geogr. 2002, 27, 67-90. [CrossRef] 
29. Hershberg, E.; Nabeshima, K.; Yusuf, S. Opening the Ivory Tower to business: University-Industry linkages and the development of knowledge-intensive clusters in Asian cities. World Dev. 2007, 35, 931-940. [CrossRef]

30. Cai, Y.; Liu, C. The roles of universities in fostering knowledge-intensive clusters in Chinese regional innovation systems. Sci. Public Policy 2015, 42, 15-29. [CrossRef]

31. Hu, T.; Chang, S.; Lin, C.; Chien, H. Evolution of knowledge intensive services in a high-tech region: The case of Hsinchu, Taiwan. Eur. Plan. Stud. 2006, 14, 1363-1385. [CrossRef]

32. Tödtling, F.; Lehner, P.; Trippl, M. Innovation in knowledge intensive industries: The nature and geography of knowledge links. Eur. Plan. Stud. 2006, 14, 1035-1058. [CrossRef]

33. Gordon, I.R.; McCann, P. Industrial clusters: Complexes, agglomeration and/or social networks? Urban Stud. 2000, 37, 513-532. [CrossRef]

34. Marshall, A.A. Principles of Economics, 8th ed.; Prometheus Books: London, UK, 1890.

35. Weber, A. Theory of the Location of Industries; University of Chicago Press: Chicago, IL, USA, 1909.

36. Lee, L.F. Asymptotic distributions of quasi-maximum likelihood estimators for spatial autoregressive models. Econometrica 2004, 72, 1899-1925. [CrossRef]

37. Kelejian, H.H.; Prucha, I. Specification and estimation of spatial auto-regressive models with auto-regressive and heteroskedastic disturbances. J. Econ. 2010, 157, 53-67. [CrossRef] [PubMed]

38. Zeng, T.Q.; Zhou, Q. Optimal spatial decision making using GIS: A prototype of a real estate geographical information system (REGIS). Int. J. Geogr. Inf. Sci. 2001, 15, 307-321. [CrossRef]

39. Alonso, W. Location and Land Use; Harvard University Press: Cambridge, MA, USA, 1964.

40. Johnston, R.J. The Location of high status residential areas. Geogr. Ann. Ser. B Hum. Geogr. 1966, 48, $23-35$. [CrossRef]

41. Caster, H. The Study of Urban Geography; Edward Amold Ltd.: London, UK, 1981.

42. Wu, F. Sociospatial differentiation in urban China: Evidence from Shanghai's real estate markets. Environ. Plan. A 2002, 34, 1591-1615. [CrossRef]

43. Meier, B.P.; Moller, A.C.; Chen, J.J.; Riemer-Peltz, M. Spatial metaphor and real estate: North-South location biases housing preference. Soc. Psychol. Personal. Sci. 2011, 2, 547-553. [CrossRef]

44. Li, F.; Zhou, C. Spatial autocorrelation analysis on regional economic disparity of northeast economic region in China. Chin. J. Popul. Resour. Environ. 2009, 7, 27-37.

45. Zhu, B.; Füss, R.; Rottke, N.B. Spatial linkages in returns and volatilities among U.S. regional housing markets. Real Estate Econ. 2013, 41, 29-64. [CrossRef]

46. Wei, A.P.; Huang, W.L.; Yang, C.Y.; Chen, M.C. The role of market imperfections in the relationship between housing prices and household credit: Evidence from Taiwan. Asian-Pac. Econ. Lit. 2013, 27, 131-143. [CrossRef]

47. Guangzhou Commercial Information Display Platform. Available online: http://cri.gz.gov.cn (accessed on 1 April 2017).

48. Guangzhou Statistics Bureau. Guangdong Statistical Yearbook. Available online: http://210.72.4.52/gzStat1/ chaxun/njsj.jsp (accessed on 1 April 2017).

49. Rogerson, P. Statistical Methods for Geography; SAGE Publications Inc.: Thousand Oaks, CA, USA, 2010.

50. Burt, J.E.; Barber, G. Elementary Statistics for Geographers; Guilford Press: Guilford, NY, USA, 1996.

51. Fotheringham, A.S.; Brunsdon, C.; Charlton, M. Quantitative Geography: Perspectives on Spatial Data Analysis; Sage: London, UK, 2000.

52. Epanechnikov, V.A. Non-parametric estimation of a multivariate probability density. J. Theory Probab. 1969, 14, 153-158. [CrossRef]

53. Mitchell, A. The ESRI Guide to GIS Analysis; ESRI Press: Redlands, CA, USA, 2005.

54. Ebdon, D. Statistics in Geopgraphy; Blackwell: Hoboken, NJ, USA, 1985.

55. Song, C.; Kulldorff, M. Power evaluation of disease clustering tests. Int. J. Health Geogr. 2003, 2, 9. [CrossRef] [PubMed]

56. Eichholtz, P.; Holtermans, R.; Yönder, E. The economic effects of owner distance and local property management in US office markets. J. Econ. Geogr. 2015, 16, 781-803. [CrossRef]

57. Guangzhou Statistics Bureau. 2015 Guangzhou Statistical Yearbook. Available online: http://www.gzstats. gov.cn (accessed on 1 April 2017).

58. Beardsell, M.; Henderson, V. Spatial evolution of the computer industry in the USA. Eur. Econ. Rev. 1999, 43, 431-456. [CrossRef] 
59. Feng, C.C.; Yeung, S.C. Real estate markets in mainland China. In International Real Estate; Blackwell Publishing Ltd.: Hoboken, NJ, USA, 2008; pp. 342-362.

60. Cheng, F.; Boerboom, L.; Geertman, S.; Hooimeijer, P. Changing spatial concentration of sectoral employment in China's Pearl River Delta 1990-2005. Tijdschr. Econ. Soc. Geogr. 2013, 104, 261-277. [CrossRef]

61. Li, K.; Wei, Q.; Zhang, X. On performance analysis of turning country into district in Panyu. Hum. Geogr. 2007, 94, 111-114.

62. Jaffe, A.B.; Trajtenberg, M.; Henderson, R. Geographic localization of knowledge spillovers as evidenced by patent citations. Q. J. Econ. 1993, 108, 577-598. [CrossRef]

63. McCann, B.T.; Folta, T.B. Demand- and supply-side agglomerations: Distinguishing between fundamentally different manifestations of geographic concentration. J. Manag. Stud. 2009, 46, 362-392. [CrossRef]

64. Wu, A.; Wang, C.C.; Li, S. Geographical knowledge search, internal R\&D intensity and product innovation of clustering firms in Zhejiang, China. Pap. Reg. Sci. 2015, 94, 553-572.

65. Garrett-jones, S. From citadels to clusters: The evolution of regional innovation policies in Australia. RED Manag. 2004, 34, 3-16.

66. Sellar, C.; Emilova, M.; Petkova-Tancheva, C.D.; McNeil, K. Cluster policies in Bulgaria: European integration, postsocialist dynamics and local level initiatives. Int. J. Urban Reg. Res. 2011, 35, 358-378. [CrossRef]

67. McCann, P.; Shefer, D. Location, agglomeration and infrastructure. Pap. Reg. Sci. 2004, 83, 177-196. [CrossRef]

68. Ma, L.J.C. Economic reforms, urban spatial restructuring, and planning in China. Prog. Plan. 2004, 61, 237-260. [CrossRef]

69. Zhang, Y.; Hua, X.; Zhao, L. Exploring determinants of housing prices: A case study of Chinese experience in 1999-2010. Econ. Model. 2012, 29, 2349-2361. [CrossRef]

70. Wu, J.; Gyourko, J.; Deng, Y. Evaluating conditions in major Chinese housing markets. Reg. Sci. Urban Econ. 2012, 42, 531-543. [CrossRef]

71. Rao, C.R. Diversity and dissimilarity coefficients: A unified approach. Theor. Popul. Biol. 1982, $21,24-43$. [CrossRef]

72. Ellison, G.; Glaeser, E.I. Geographic concentration in U.S. manufacturing industries: A dartboard approach. J. Political Econ. 1997, 105, 889-927. [CrossRef]

73. Duranton, G.; Overman, H.G. Testing for localization using micro-geographic data. Soc. Sci. Electron. Publ. 2002, 72, 1077-1106. [CrossRef] 